\title{
Ecophysiological study of SiK impact on Castanea sativa Mill. tolerance to drought stress
}

\author{
A. CARNEIRO-CARVALHO ${ }^{*,+}$, R. ANJOS*, J. LOUSADA*, T. MARQUES ${ }^{* *}$, T. PINTO*, \\ and J. GOMES-LARANJO* \\ CITAB - Centre for the Research and Technology of Agro-Environmental and Biological Sciences, University \\ of Tras-os-Montes and Alto Douro (UTAD), Vila Real, Portugal* \\ Student of Biochemistry, University of Trás-os-Montes and Alto Douro (UTAD), Vila Real, Portugal ${ }^{* *}$
}

\begin{abstract}
Drought is an abiotic stress that may be aggravated by climate changes with increasingly warmer and drier summers. This is a severe problem in the chestnut crop in Portugal due to its need for water during this time, which is essential for good formation and development of the fruit. Si fertilization is referenced by several authors as important in the tolerance of plants under drought. The experiments were carried out in the field trial and chestnuts were fertilized with $0,5,7.5$, and $10 \mathrm{mM}$ potassium silicate (SiK), which was applied to the soil and to the leaves and exposed to a non-irrigation and an irrigation phase during the summer. Results indicate that Si fertilization increased the relative water content and water potential, while the transpiration rate, stomatal conductance, and stomatal density were reduced under deficit irrigation in Si-treated plants (10 mM SiK). Moreover, the Si induces a higher photosynthetic activity and vessel frequency with a smaller diameter, promoting a higher relative hydraulic conductivity and a lower vulnerability to cavitation. This work suggests that Si can be used as a potential source to induce drought tolerance in chestnuts.
\end{abstract}

Additional key words: phytoliths; transpiration; water stress; water uptake.

\section{Introduction}

Climate change induces significant regional variations in weather, while increasing the frequency and intensity of extreme values, which impairs crops and reduces their yields, leading to major shifts in food production (Rosenzweig et al. 1993). In the Mediterranean region of Europe, the combination of high temperatures and precipitation scarcity during drought periods (Lionello et al. 2014) represent important stress factors that limit chestnut fruit development.

Drought is one of the major constraints limiting crop production worldwide by impairing the normal growth, disturbing water relations, and reducing water-use efficiency in plants (Pimentel 1993, Farooq et al. 2012). In Portugal, due to the scarcity of precipitation during the summer, combined with high evapotranspiration rates, drought periods are frequent and have disastrous consequences for agriculture.

Chestnut (Castanea sativa Mill.) is one of the most important crops in the mountainous regions of the north and centre of Portugal, where 35,000 hectares are estimated to be occupied by this crop. The chestnut species is a medium-large, warm-temperate deciduous species, which likes a mean yearly temperature ranging between 8 and $15^{\circ} \mathrm{C}$ and monthly mean temperatures over $10^{\circ} \mathrm{C}$ for six months (Conedera et al. 2016). This species needs a minimum annual rainfall ranging between 600 and $800 \mathrm{~mm}$, according to its distribution and interaction with temperatures. Due to climate constraints, most of the chestnut orchards are facing serious restrictions caused by drought and heat stress during the entire summer. Consequently, tree vigor and health diminish, leading to a decrease in the production and quality of the fruits. This is a serious problem that is currently affecting all the Mediterranean countries that are chestnut producers (Krebs et al. 2004, Mattioni et al. 2008, Mellano et al. 2012).

The adequate tree water level is extremely important to allow a stabilization of production that is more independent from the summer rainfall since it could influence fruit setting, fruit size, and biochemical composition (Aguiar

Received 17 August 2019, accepted 25 March 2020.

${ }^{+}$Corresponding author; e-mail: andreiamcc_500@hotmail.com

Abbreviations: Chl - chlorophyll; Chl $(a+b)$ - total chlorophyll; Chl/Car - chlorophyll to carotenoids ratio; DM - dry mass; $E$ - transpiration rate; $g_{\mathrm{s}}$ - stomatal conductance; IP - irrigation phase; NIP - non-irrigation phase; $P_{\mathrm{N}}$ - net photosynthetic rate; $\mathrm{RC}$ - relative hydraulic conductivity; RWC - relative water content; SD - stomatal density; Si - silicon; SiK - potassium silicate; $\mathrm{VA}$ - vessel area; VD - vessel diameter; VF - vessel frequency; WUE - water-use efficiency $\left(=P_{\mathrm{N}} / E\right) ; \Psi_{\mathrm{w}}-$ water potential. Acknowledgements: The authors would like to acknowledge Mrs. Cesaltina Machado, Mrs. Donzilia Costa, and Mrs. Helena Ferreira for their help with the assay installation. We thank Mr. Armindo Teixeira for his invaluable suggestions concerning the elaboration of xylem histological sections. We also thank for the support provided by the National Funds by FCT - Portuguese Foundation for Science and Technology, under the project UID/AGR/04033/2019. 
2009, Mota et al. 2018). For the typical Portuguese edaphoclimatic conditions, these authors estimated a need for around $400 \mathrm{~mm}$ of water during the summer (between flowering and fruit fall), which should be compensated by rainfall or irrigation. These authors reported a harvest reduction of around $50 \%$ whenever rainfall or irrigation during that period was absent to help reach this ideal water amount. For these reasons, changes in the frequency and severity of droughts could require an innovative management approach to save trees against water stress damages.

Silicon (Si) has a vital role in agriculture, providing many benefits to the plants through biochemical and physiological processes, by promoting a decrease of environmental stresses. Furthermore, $\mathrm{Si}$ is considered by many authors as an antistress agent that can reduce transpiration, cell membrane damage, and increase leaf relative water content in the plants (Mauad et al. 2016). Many studies show that $\mathrm{Si}$ application in crops under water stress also enhances the activity of antioxidant enzymes and the contents of ascorbic acid and glutathione by improving the capacity of water absorption and, consequently, the root hydraulic conductance (Shi et al. 2016). In addition, Simediated antioxidant defense increases the photosynthesis activity and has an important role in keeping the mineral balance in plants through the Si-mitigated soil nutrient depletion, increasing their fertility (Othomani et al. 2016). Preliminary studies on chestnut plants (Zhang et al. 2013) suggest that Si can improve chestnut photosynthesis and growth, inducing loss of water more quickly, thus making it more susceptible to water stress, but it can also increase their heat stress tolerance.

The main aim of the present research was to evaluate the effect of $\mathrm{SiK}$ fertilization on the improvement of drought stress tolerance in chestnuts plants (Castanea sativa Mill.) through an ecophysiological study.

\section{Materials and methods}

Experimental design and treatments: The experiments were carried out at the University of Trás-os-Montes and Alto Douro, Vila Real, Portugal (41 $\left.{ }^{\circ} 17^{\prime} 20^{\prime \prime} \mathrm{N}, 7^{\circ} 44^{\prime} 0^{\prime \prime} \mathrm{W}\right)$. Chestnut seedlings of the Sousã variety were planted in 2-L plastic pots filled with $70 \%$ of turf and $30 \%$ of perlite and regularly watered with the same water volume. The plants remained in the same pots throughout the study. The pots were arbitrarily distributed into four groups, with 30 replications carried out per group, and maintained in the field with an automatic irrigation system all over the study plants, as shown in Fig. 1S (supplement). The climatic conditions during the assay period of the test were mentioned in Table 1S (supplement).

The pots were arranged on the farm before the emergence of leaves at the end of February. The plantlets were randomly organized into four groups of 30 pots each (Fig. 1S). Plantlets were watered daily by a programmed drip-irrigation system from the end of May until the start of the water deficit experiments (Fig. 1S). Normal growth conditions were maintained for a period of five months until the beginning of the experiments. The present study lasted three years; in the first year only Si fertilization was performed, in the following two years, different parameters were analyzed to evaluate the effect of Si under drought. Regarding the age and size of the plants used in this work: in 2014, they were one-year old and on average of $15 \mathrm{~cm}$ in height, in 2015, they were two-years old and $40 \mathrm{~cm}$ high, and in 2016, they were three-years old and $80 \mathrm{~cm}$ high.

In this work, we used potassium silicate as a source of silicon as it is one of the fertilizers with the greatest positive effects obtained in several crops (Zhang et al. 2013). The chestnut plants were fertilized with potassium silicate (SiK) at $0,5,7.5$, and $10 \mathrm{mM} \mathrm{SiK}$. The concentrations of $\mathrm{SiK}$ were selected according to the results obtained in the previous study on chestnut plants published by Zhang et al. (2013). The $\mathrm{SiK}$ ( $\mathrm{pH}$ adjusted to 6.8 by $\mathrm{HCl}$ ), containing $0.30 \%$ soluble $\mathrm{Si}$ and $0.10 \% \mathrm{~K}$, was applied in two ways, directly into the soil $(50 \mathrm{~mL})$ and on the leaves $(30 \mathrm{~mL})$ by foliar application in the mornings (at 10:00 h) in April. Plants were submitted to annual SiK applications between 2014 and 2016, always three months before the experiment. The results present here were those from 2015 and 2016.

This study was conducted in the summer when temperatures were the highest and the weather dry, so the plants did not receive any rainwater. Therefore, all the plants were submitted to a first phase without irrigation (NIP) to induce water stress in the plants. When the first plants reached their threshold of water potential -2.0 MPa, the irrigation was started (second phase - IP). A drip system (4 L/drip/plant) was installed to ensure the irrigation. During the irrigation phase, irrigation was carried out on a daily basis, with a 15 -min duration.

The study was carried out in 2015 , however, we decided to repeat the study again in 2016 , in order to increase and reinforce our results. Leaf samples were collected after the exposure to water stress in the non-irrigation phase (NIP) and after the irrigation phase (IP), when plants reached the highest water potential.

Si concentration: The content of $\mathrm{Si}$ was analysed according to the method described by Korndörfer et al. (2004), through colorimetric analysis of the alkaline digestion of $0.1 \mathrm{~g}$ of dry leaf tissue. Leaf silicon determination was carried out twice, at the end of the NIP and during the IP. The measurement was replicated three times per treatment $(n=3)$.

Water potential $\left(\Psi_{\mathrm{w}}\right)$ and relative water content (RWC): Five leaves from each treatment were used to measure the stem water potential $\left(\Psi_{\mathrm{w}}\right)$ with a Scholander pressure chamber (PMS Instrument Company, Albany, USA). The leaves were covered with a reflective plastic bag for $10 \mathrm{~min}$ to promote the balance between leaf water tension and the stem water tension. After that, the leaves were placed in a pre-weighed airtight vial to determine the relative water content (RWC). In the laboratory, the vials were weighed (to determine fresh mass), then they were opened and filled with demineralized water and kept in the 
dark at $4^{\circ} \mathrm{C}$ for $24 \mathrm{~h}$ to determine the turgid mass (TM). After that, the leaves were dried at $60^{\circ} \mathrm{C}$ for $48 \mathrm{~h}$ to obtain the dry mass (DM). The RWC was calculated according to Salisbury and Ross (1969). These measurements of $\Psi_{\mathrm{w}}$ were carried out between 10 and $12 \mathrm{~h}$

Leaf samples were collected for the measurements at $0,4,6$, and $12 \mathrm{~d}$ in the NIP and again at $13,15,17,20,26$, and $34 \mathrm{~d}$ in the IP to assess their ability to recover from stress in 2015. In 2016, leaf samples were collected for the measurements at $0,4,7$, and $12 \mathrm{~d}$ in the NIP and at 13,16 , $20,24,27,31$, and $34 \mathrm{~d}$ in the IP to assess their ability to recover from the stress.

Leaf stomatal density: The imprints of the epidermis of chestnut leaves were made to determine leaf stomatal density, which was expressed as the number of stomata per unit leaf area, according to $\mathrm{Xu}$ and Zhou (2008). The abaxial epidermis of the fresh leaves was cleaned and brushed with collodion in the mid-area between the central vein and the leaf. After $15 \mathrm{~min}$, the pellicle was carefully removed from the leaf surface and mounted on a microscope slide with water. The observations of the imprints were made using an Olympus IX51 inverted microscope (Olympus Optical Co., GmbH, Hamburg, Germany), connected to a camera Olympus BX50. Leaf samples were collected at the end of the study and three replications were carried out per treatment, with two quantifications per sample.

Xylem anatomy: Measurements were carried out according to Twumasi et al. (2005), with minor modifications. A cross section of $2 \mathrm{~cm}$ was cut from the middle of the lowest internode of each stem sample. Then, stem cross sections of $20 \mu \mathrm{m}$ were made using the microtome. The samples were placed on glass microscope slides, with a mixture of alcohol-glycerol ( $86 \%$ ). The stem samples from the chestnut plants were collected at the end of the study and three replications per plant were made for analysis.

The digital images of the stem sections were made using Marlin F-145 3 camera with the Nikon SMZ 10 magnifying glass: whole cross sections magnification was $20 \times$. The area, diameter, and number of xylem vessels were calculated from previous images, using 2 or $3 \mathrm{~mm}^{2}$ squares, depending on the size of the stem, to measure the xylem vessels in four different quadrants of the stem. The measurements were carried out using the AVT Smart View 7.2 and Image Pro Plus 6.2, for the image treatment. The number, diameter, and area of xylem vessels were measured.

The variation of efficiency and susceptibility to damage caused by the vessel diameter was estimated indirectly by the relative hydraulic conductivity (RC) and the vulnerability to cavitation, according to the equations of Gutiérrez et al. (2009). The RC and vulnerability were estimated in each plant as:

$\mathrm{RC}=\mathrm{r}^{4} \mathrm{VF}$

Vulnerability $=\mathrm{VD} / \mathrm{VF}$

where $r$ is the vessel diameter, VF is vessel frequency in a square $\mathrm{mm}$ and $\mathrm{VD}$ is the vessel diameter in a square $\mathrm{mm}$.
Gas-exchange: The gas-exchange parameters, net photosynthetic rate $\left(P_{\mathrm{N}}\right)$, transpiration rate $(E)$, and stomatal conductance $\left(g_{\mathrm{s}}\right)$ of expanded leaves were evaluated with a portable gas-exchange system (IRGA, LCpro + , Analytical Development $\mathrm{Co}^{\circledR}$, Hoddesdon, UK). The water-use efficiency (WUE) was determined by the ratio $P_{\mathrm{N}} / E$, according to Zhang et al. (2013). The measure-ments were made between 10:00 and 12:00 h, with a PPFD of $1,600 \mu \mathrm{mol}$ (photon) $\mathrm{m}^{-2} \mathrm{~s}^{-1}$. The results corresponded to replication of 12 times per treatment $(n=12)$.

Photosynthetic pigments were determined using four discs $(8 \mathrm{~mm})$ from each leaf $(n=5)$. The extraction was done with $80 \%$ acetone $(\mathrm{v} / \mathrm{v})$, according to the method developed by Šesták et al. (1971) and Lichtenthaler (1987). Leaf samples were collected after the exposure to water stress in the NIP and after the IP, when plants reached their highest water potential.

Statistical analysis: All the data were subjected to statistical analysis using Statview (BrainPower Inc., California) and Statistic 8.0 (StatSoft Europe, Germany). Analysis of variance $(A N O V A)$ was also performed among the data treatments, using the Tukey's test $(P<0.05)$.

\section{Results}

Si concentration in leaf tissue: The determinations were carried out at the end of each phase. The results showed that the Si content increased in the plants fertilized with $\mathrm{Si}$ after the NIP period from 1.79 to $3.17 \mathrm{mg}(\mathrm{Si})$ per plant representing an increase of $77 \%$ (Table 1) in 2015. At the NIP, the increase of about $504 \%$ was observed for untreated (0 $\mathrm{mM} \mathrm{SiK})$ compared to the Si-treated plants $(10 \mathrm{mM}$ $\mathrm{SiK}$ ) in 2016. Similar results were observed in the IP phase, with the higher Si content observed at 5, 7.5, and $10 \mathrm{mM}$ $\mathrm{SiK}$, i.e., 1.97, 2.75, and $3.34 \mathrm{mg}(\mathrm{Si})$ per plant. Moreover, the results indicate that there was a significant increase in the $\mathrm{Si}$ content in the NIP from $2015,3.17 \mathrm{mg}(\mathrm{Si})$ per plant (10 mM SiK) to $5.44 \mathrm{mg}(\mathrm{Si})$ per plant $(2016,10 \mathrm{mM} \mathrm{SiK})$. Similar results were observed in the IP phase, from 3.34 to $5.03 \mathrm{mg}(\mathrm{Si})$ per plant, representing an increase of about $51 \%$, suggesting that annual $\mathrm{Si}$ applications can increase the accumulation in plant tissues. Contrarily, the Si content diminished in the untreated plants, being higher in the NIP, $1.79 \mathrm{mg}(\mathrm{Si})$ per plant, than that in the IP treatment, $1.60 \mathrm{mg}(\mathrm{Si})$ per plant.

Survival rate of chestnut plants under drought stress: After two years of the experiment, significant differences were observed between the Si-treated plants and untreated plants. Data showed that the Si-treated plants recorded a $100 \%$ survival rate, while for the untreated plants, only $30 \%$ survived after two years of the assay being exposed to the NIP (Fig. 2S, supplement).

Water relations parameters: At the beginning of the study $(0 \mathrm{~d})$, a significant difference in $\Psi_{\mathrm{w}}$ was observed between the untreated and Si-treated plants. Analyzing the NIP, the results indicate that the threshold $\Psi_{\mathrm{w}}$ of $-2.0 \mathrm{MPa}$ 
was first reached in the untreated plants $(0 \mathrm{mM} \mathrm{SiK})$ in both years on the $12^{\text {th }} \mathrm{d}$ after irrigation was stopped, while in the Si-treated plants $(10 \mathrm{mM} \mathrm{SiK})$, we recorded only $\Psi_{\mathrm{w}}$ of $-1.5 \mathrm{MPa}$ (Fig. 1), with the exception of the $5 \mathrm{mM}$ $\mathrm{SiK}$ treatment in the $2^{\text {nd }}$ year when the plants reached $\Psi_{\mathrm{w}}$ of $-1.7 \mathrm{MPa}$.

Concerning the second phase, called the recovery phase (IP), due to the reintroduction of irrigation, the recovery pattern was faster in 2015 than that in 2016. The results also suggest a major difference in the time needed

Table 1. The Si content $[\mathrm{mg}(\mathrm{Si})$ per plant $]$ in chestnut leaves from plants treated with different concentration of $\mathrm{Si}(0,5,7.5$, and $10 \mathrm{mM} \mathrm{SiK}$ ) and exposed to a non-irrigation phase (NIP) and an irrigation phase (IP), with three replications per treatment $(n=3)$. Different lowercase letters mean significant differences between different treatments at the same time according to the Tukey's test $(P \leq 0.05)$. Different capital letters mean significant differences between the same treatment all over the time according to the Tukey's test $(P \leq 0.05)$.

\begin{tabular}{lllll}
\hline Treatment $[\mathrm{mM}]$ & $\begin{array}{l}2015 \\
\text { NIP }\end{array}$ & IP & $\begin{array}{l}2016 \\
\text { NIP }\end{array}$ & IP \\
\hline 0 & $1.79^{\mathrm{bA}}$ & $1.60^{\mathrm{bA}}$ & $0.90^{\mathrm{cA}}$ & $0.67^{\mathrm{cA}}$ \\
5 & $3.06^{\mathrm{aA}}$ & $1.97^{\mathrm{bB}}$ & $3.45^{\mathrm{bA}}$ & $3.10^{\mathrm{bA}}$ \\
7.5 & $3.79^{\mathrm{aA}}$ & $2.75^{\mathrm{aA}}$ & $4.89^{\mathrm{aA}}$ & $4.50^{\mathrm{aA}}$ \\
10 & $3.17^{\mathrm{aA}}$ & $3.34^{\mathrm{aA}}$ & $5.44^{\mathrm{aA}}$ & $5.03^{\mathrm{aA}}$ \\
\hline
\end{tabular}

to recover from the NIP between the Si-treated $(10 \mathrm{mM}$ $\mathrm{SiK})$ and the untreated plants $(0 \mathrm{mM} \mathrm{SiK})$, being faster for the first ones. As shown in Fig. 1A, the Si-treated plants needed $1 \mathrm{~d}$ in 2015 to recover from the water stress, while in 2016, they needed $7 \mathrm{~d}$. The untreated plants did not recover from the drought, with the values recorded not reaching the initial $\Psi_{\mathrm{w}}$ values at the end of the experiment (Fig. 1), i.e., around $-0.8 \mathrm{MPa}$ (higher than that verified at the beginning) in the Si-treated plants $(10 \mathrm{mM} \mathrm{SiK})$ and $-1.3 \mathrm{MPa}$ in the untreated plants (0 mM SiK).

The variation pattern of the relative water content (Fig. 2) was quite similar to that observed for $\Psi_{\mathrm{w}}$ (Fig. 1). In the first phase (NIP), the relative water content (RWC) in untreated plants $(0 \mathrm{mM} \mathrm{SiK})$ decreased by about $242 \%$ in 2015 (Fig. 2A) and 475\% in 2016 (Fig. 2B), while in Si-treated plants (10 mM SiK) it decreased only by $14 \%$ in 2015 (Fig. $2 A$ ) and $22 \%$ in 2016 (Fig. 2B).

Analyzing the IP, a complete recovery was observed in all treatments in both years (Fig. 2). Although at the end of the study, the RWC of untreated plants $(0 \mathrm{mM} \mathrm{SiK})$ was lower than that observed for other plants. Nevertheless, the time needed to reach the normal RWC was very fast for the Si-treated plants $(1 \mathrm{~d})$, while for the untreated plants (0 mM SiK), it was $16 \mathrm{~d}$ (2015; Fig. $2 A)$ and $18 \mathrm{~d}$ (2016; Fig. 2B), respectively. Furthermore, the $5 \mathrm{mM} \mathrm{SiK}$ treatment showed a lower RWC at the end of the NIP in 2016 (Fig. 2B) compared to other Si-treated plants. When comparing the NIP and IP, Fig. 2 shows that Si

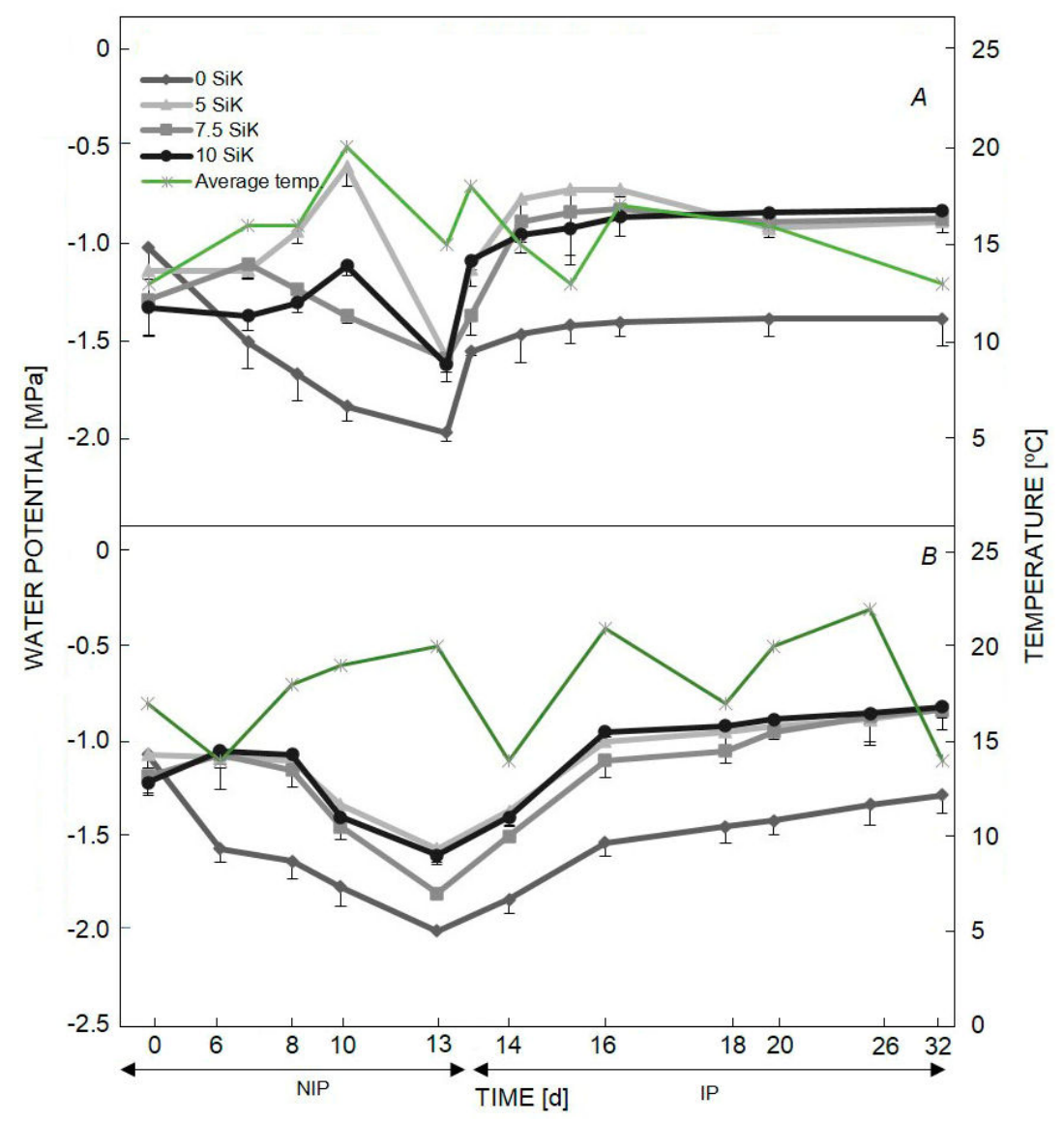

Fig. 1. Variation in the water potential of chestnut plants in $2015(A)$ and $2016(B)$, in response to different $\mathrm{SiK}$ concentrations $(0$, $5,7.5$, and $10 \mathrm{mM} \mathrm{SiK}$ ) in the non-irrigation phase (NIP) and the irrigation phase (IP), according to average temperature in Vila Real $\left[{ }^{\circ} \mathrm{C}\right]$. Each value is the mean $\pm \mathrm{SE}$ of three replicates $(n=3)$. 
fertilization helped preserve the RWC between $60-80 \%$ in the NIP, while reached critical values of 21 and $12 \%$ in the untreated plants $(0 \mathrm{mM} \mathrm{SiK})$ plants. This pattern was coherent with lower values of $\Psi_{w}$ verified for the same plants (Fig. 1). Apparently, the induced stress in the first phase increased the capacity of Si-treated plants to absorb water when available.

Stomatal density (SD) was examined only at the end of the study in 2016. Data showed significant differences in SD between the Si-treated plants and the untreated plants (Figs. 3; 3S, supplement). The observation of the epidermis from the abaxial leaf side (Fig. 4) suggests that the Si-treated plants exhibited the lower SD comparatively to untreated plants.

The results indicated that the increase in SiK concentration induced a significant reduction in $\mathrm{SD}$, i.e., 256.5, 220.4, and $201.8 \mathrm{~mm}^{-2}$ (Fig. 3), for 5, 7.5, and $10 \mathrm{mM} \mathrm{SiK}$ treatments, respectively, while the untreated plants $(0 \mathrm{mM}$ SiK) showed $292.9 \mathrm{~mm}^{-2}$ (Fig. 3), representing a drop of $45 \%$ between 0 and $10 \mathrm{mM} \mathrm{SiK}$-treated chestnut plants.

Xylem anatomy: The microscopic images (Fig. 4S, supplement) indicate an increase in the diameter and frequency of xylem vessels in the Si-treated plants. The untreated plants (0 mM SiK) present the lowest xylem area, $20.0 \mathrm{~mm}^{2}$, while the Si-treated plants recorded an increase in this parameter proportional to the increase of $\mathrm{Si}$ concentrations applied to chestnut plants, $27 \%$ (5 $\mathrm{mM} \mathrm{SiK}$ ), 31\% (7.5 mM SiK) and 50\% (10 mM SiK) when compared with the untreated plants $(0 \mathrm{mM} \mathrm{SiK})$ (Table 2$)$. As shown in Table 2, the results of the stem area in the Si-treated plants were higher than that in the untreated plants.

The vessel frequency (VF) was significantly higher in the Si-fertilized plants than that of untreated plants, showing an enhancement of $53 \%$ between $0 \mathrm{mM}$ and $10 \mathrm{mM} \mathrm{SiK}$ treatments (Table 2). Plants from $7.5 \mathrm{mM}$ and $10 \mathrm{mM} \mathrm{SiK}$ treatments showed the lower diameter (VD) values for the xylem vessels, 28.0 and $28.5 \mu \mathrm{m}$, respectively, compared to the untreated plants $(0 \mathrm{mM} \mathrm{SiK}), 33.7 \mu \mathrm{m}$. Relatively to the vessel area (VA), the Si-treated plants recorded lower values of this parameter, $799.3 \mu \mathrm{m}^{2}(10 \mathrm{mM} \mathrm{SiK})$, than that of the untreated plants, $1,005.5 \mu \mathrm{m}^{2}(0 \mathrm{mM} \mathrm{SiK})$, with a reduction of about $26 \%$ (Table 2 ).

This vulnerability indicates susceptibility to cavitation in the water column and the RC indicated the efficiency of xylem vessels for conducting water. Relatively to the vulnerability parameter, data showed a reduction of about

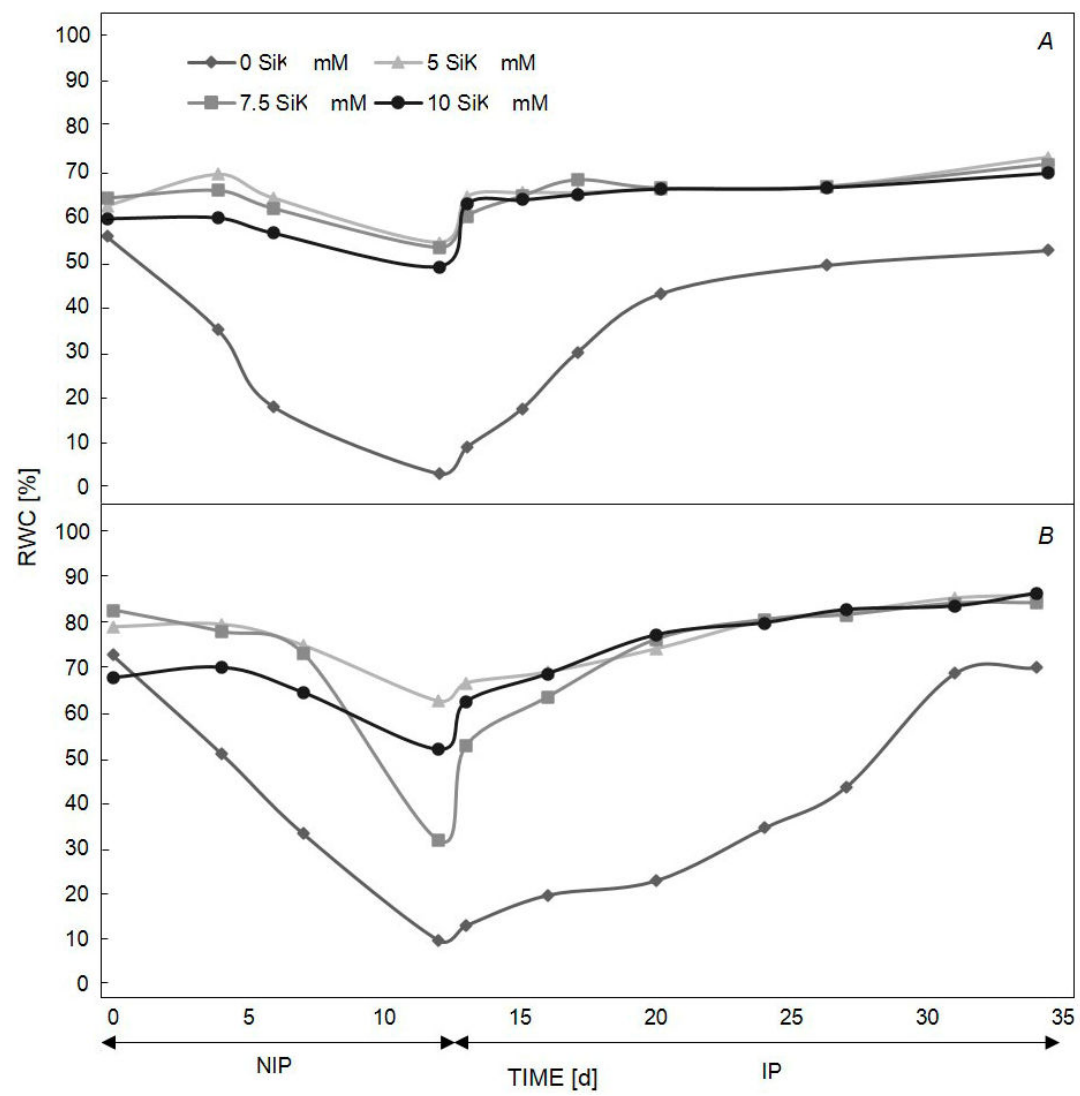

Fig. 2. Effect of $\mathrm{SiK}$ fertilization $(0,5,7.5$, and $10 \mathrm{mM} \mathrm{SiK})$ on relative water content (RWC) during the non-irrigation phase (NIP) and the irrigation phase (IP) in 2015 $(A)$ and $2016(B)$ measurements. Each value is the mean $\pm \mathrm{SE}$ of three replicates per treatment $(n=3)$.

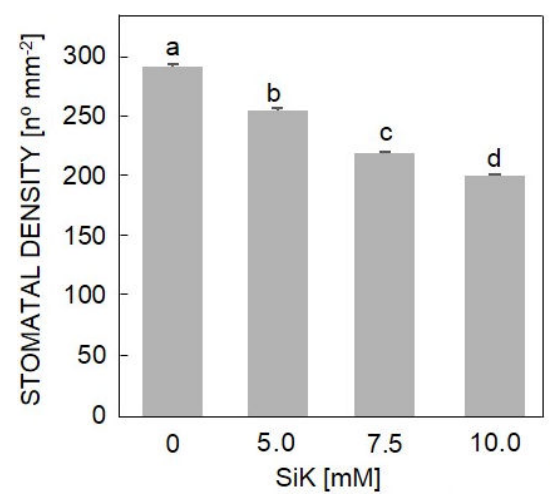

Fig. 3. The effect of Si application $(0,5$, 7.5 , and $10 \mathrm{mM} \mathrm{SiK}$ ) on stomata density of chestnut plants. Different lowercase letters indicate significant differences between treatments according to the Tukey's test $(P \leq 0.05)(n=4)$. 

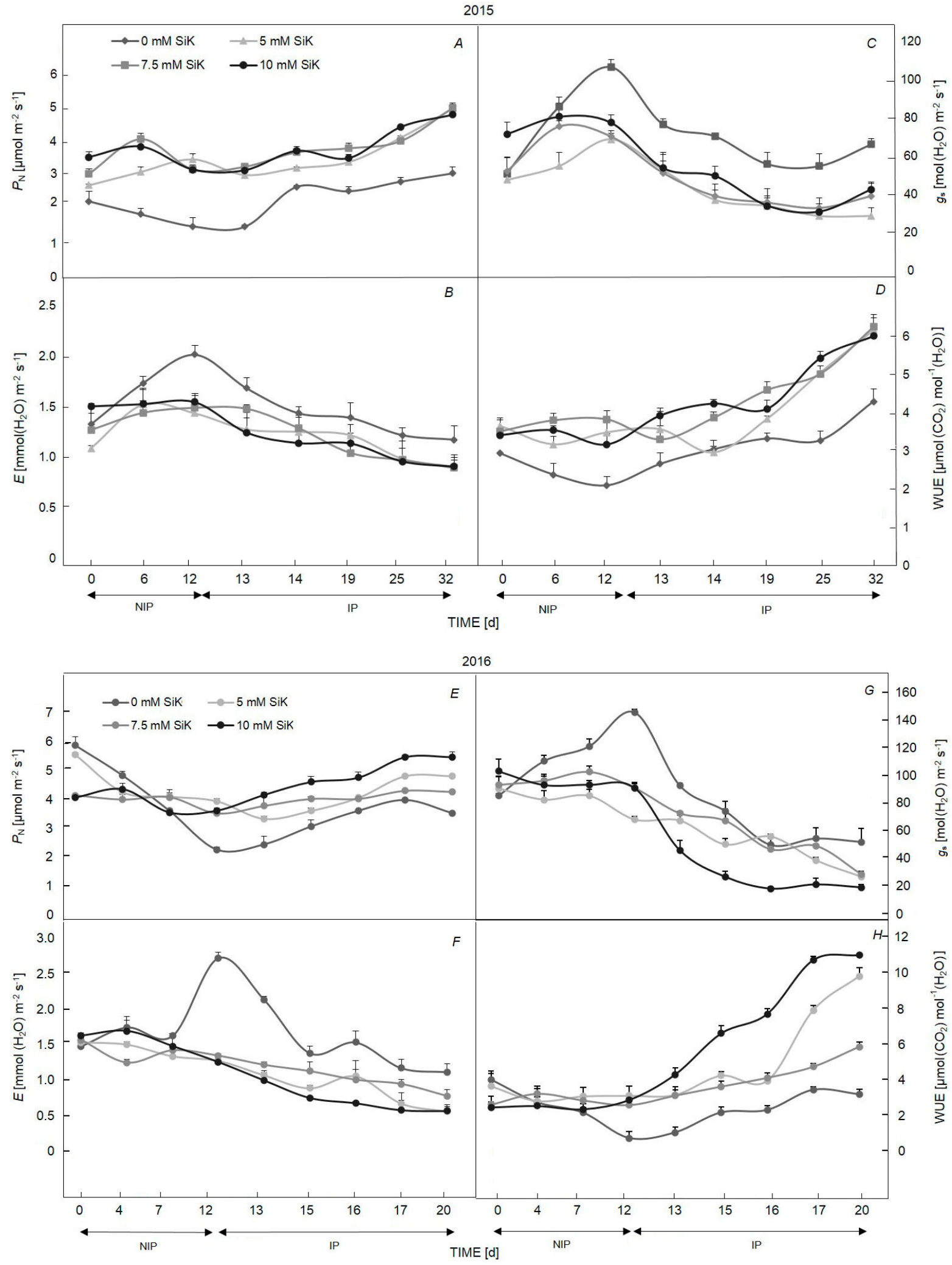

Fig. 4. Gas-exchange measurements of $2015(A-D)$ and $2016(E-H)$ : net photosynthetic rate $\left(P_{\mathrm{N}}\left[\mu \mathrm{mol} \mathrm{m}^{-2} \mathrm{~s}^{-1}\right]\right)(A-2015, E-2016)$, transpiration rate $\left(E\left[\mathrm{mmol}\left(\mathrm{H}_{2} \mathrm{O}\right) \mathrm{m}^{-2} \mathrm{~s}^{-1}\right]\right)(B-2015, F-2016)$, stomatal conductance $\left(\mathrm{g}_{\mathrm{s}}\left[\mathrm{mol}\left(\mathrm{H}_{2} \mathrm{O}\right) \mathrm{m}^{-2} \mathrm{~s}^{-1}\right]\right)(C-2015, G-2016)$, and water-use efficiency (WUE $\left.\left[\mu \mathrm{mol}\left(\mathrm{CO}_{2}\right) \mathrm{mol}^{-1}\left(\mathrm{H}_{2} \mathrm{O}\right)\right]\right)(D-2015, H-2016)$ during the non-irrigation phase (NIP) and the irrigation phase (IP) for chestnut plants fertilized with $0,5,7.5$, and $10 \mathrm{mM} \mathrm{SiK}$. Data are the mean of 12 replicates per treatment $(n=12)$ and the vertical bars represent the standard errors (SE). 
Table 2. The effect of the application of different concentrations of Si $(0,5,7.5$, and $10 \mathrm{mM} \mathrm{SiK})$ on the xylem area [mm²], vessel frequency $\left(\mathrm{VF}\left[\mathrm{mm}^{-2}\right]\right)$, vessel diameter $(\mathrm{VD}[\mu \mathrm{m}])$, vessel area $\left(\mathrm{VA}\left[\mu \mathrm{m}^{2}\right]\right)$, vulnerability of the xylem vessel to cavitation $\left[\mu \mathrm{m} \mathrm{mm} \mathrm{m}^{-2}\right]$, and relative hydraulic conductivity $\left(\mathrm{RC}\left[\mu \mathrm{m} \mathrm{mm}^{-2}\right]\right)$. Different lowercase letters indicate significant differences between different treatments according to the Tukey's test $(P \leq 0.05)$.

\begin{tabular}{lllllll}
\hline Treatment $[\mathrm{mM}]$ & Xylem area $\left[\mathrm{mm}^{2}\right]$ & VF $\left[\mathrm{mm}^{-2}\right]$ & VD $[\mu \mathrm{m}]$ & VA $\left[\mu \mathrm{m}^{2}\right]$ & Vulnerability $\left[\mu \mathrm{mm}^{-2}\right]$ & $\mathrm{RC}\left[\mu \mathrm{m} \mathrm{mm} \mathrm{mm}^{-2}\right]$ \\
\hline 0 & $20.0^{\mathrm{c}}$ & $53.2^{\mathrm{d}}$ & $33.7^{\mathrm{a}}$ & $1,005.5^{\mathrm{a}}$ & $0.244^{\mathrm{a}}$ & $4.0^{\mathrm{c}}$ \\
5 & $25.4^{\mathrm{b}}$ & $66.1^{\mathrm{c}}$ & $30.2^{\mathrm{b}}$ & $965.2^{\mathrm{b}}$ & $0.173^{\mathrm{b}}$ & $4.5^{\mathrm{b}}$ \\
7.5 & $26.1^{\mathrm{b}}$ & $73.7^{\mathrm{b}}$ & $28.0^{\mathrm{c}}$ & $880.7^{\mathrm{c}}$ & $0.165^{\mathrm{b}}$ & $4.7^{\mathrm{b}}$ \\
10 & $29.9^{\mathrm{a}}$ & $81.3^{\mathrm{a}}$ & $28.5^{\mathrm{c}}$ & $799.3^{\mathrm{d}}$ & $0.141^{\mathrm{b}}$ & $5.8^{\mathrm{a}}$ \\
\hline
\end{tabular}

$73 \%$ between the Si-treated (10 $\mathrm{mM} \mathrm{SiK})$ and untreated plants $(0 \mathrm{mM} \mathrm{SiK})$. Data are in coherence with the higher values of RC achieved in the Si-treated plants, $5.8 \mu \mathrm{m}$ $\mathrm{mm}^{-2}$ (10 mM SiK; Table 2), while the untreated plants $(0 \mathrm{mM} \mathrm{SiK})$ recorded the lowest value of $4.0 \mu \mathrm{m} \mathrm{mm}^{-2}$ ( $0 \mathrm{mM} \mathrm{SiK}$; Table 2), representing an improvement of $45 \%$ in this parameter. The results suggest that $\mathrm{Si}$ promoted an efficient water flux inside xylem vessels under drought conditions.

Gas-exchange: Fig. 4 shows the effect of Si fertilization on gas-exchange parameters for the IP and the NIP in 2015 and in 2016. The NIP was evaluated along $12 \mathrm{~d}$ for both years, while the IP was measured between the $13^{\text {th }}$ and $32^{\text {th }} \mathrm{d}$ in 2015 and between the $13^{\text {th }}$ and $20^{\text {th }} \mathrm{d}$ in 2016. The gas-exchange measurements varied significantly, depending on the absence/presence of drought and on the Si concentration applied to the plants (Fig. 4). In relation to the net photosynthetic rate $\left(P_{\mathrm{N}}\right)$, the untreated plants (0 mM SiK) showed a significant decrease of this parameter of about $40 \%$ (2015) and $73 \%$ (2016) between 0 and $12 \mathrm{~d}$. In contrast, the Si-treated plants showed the highest values of $P_{\mathrm{N}}$ with a slight decrease of $11 \%$ (2015; Fig. $\left.4 A\right)$ and 22\% (2016; Fig. $4 E)$ in $10 \mathrm{mM} \mathrm{SiK}$ treatment.

At the end of the NIP, when plants reached the minimum value of $\Psi_{\mathrm{w}}, P_{\mathrm{N}}$ was $1.71 \mu \mathrm{mol} \mathrm{m} \mathrm{s}^{-2} \mathrm{~s}^{-1}(2015$; Fig. $4 A)$ and $2.11 \mu \mathrm{mol} \mathrm{m}{ }^{-2} \mathrm{~s}^{-1}$ (2016; Fig. $4 E$ ) in the untreated plants $(0 \mathrm{mM} \mathrm{SiK})$, whereas in $10 \mathrm{mM}$ Si-treated plants, $P_{\mathrm{N}}$ was $3.21 \mu \mathrm{mol} \mathrm{m} \mathrm{m}^{-2} \mathrm{~s}^{-1}$ (2015; Fig. $4 A$ ) and $3.47 \mu \mathrm{mol} \mathrm{m} \mathrm{m}^{-2} \mathrm{~s}^{-1}$ (2016; Fig. 4E), thus $89 \%$ (2015) and 65\% (2016) higher than in the untreated plants $(0 \mathrm{mM} \mathrm{SiK})$, respectively.

Relatively to the IP, a gradual increase of $P_{\mathrm{N}}$ from the $13^{\text {th }} \mathrm{d}$ was observed in the Si-treated plants, recording higher values at the end of the study, compared to the initial ones. The rate of $P_{\mathrm{N}}$ was $4.68 \mu \mathrm{mol} \mathrm{m} \mathrm{s}^{-2} \mathrm{~s}^{-1}$ (2015; Fig. $4 A$ ) and $5.35 \mu \mathrm{mol} \mathrm{m}{ }^{-2} \mathrm{~s}^{-1}$ (2016; Fig. $4 E$ ) in $10 \mathrm{mM}$ $\mathrm{SiK}$ treatment, while for the untreated plants $(0 \mathrm{mM} \mathrm{SiK})$, it was $3.21 \mu \mathrm{mol} \mathrm{m}{ }^{-2} \mathrm{~s}^{-1}$ (Fig. $4 A$ ) and $3.39 \mu \mathrm{mol} \mathrm{m}{ }^{-2} \mathrm{~s}^{-1}$ (Fig. 4E) in 2015 and 2016, respectively.

In terms of the transpiration rate ( $E$; Fig. $4 B)$ and the stomatal conductance $\left(g_{\mathrm{s}}\right.$; Fig. $\left.4 C\right)$, the untreated plants during the NIP presented a significant increase in these parameters, about 56 and $104.7 \%$, respectively, in $E$ and $g_{\text {s }}$ between 0 and $12^{\text {th }} \mathrm{d}$ (maximal water stress) in 2015 . However, during the IP, all treatments showed similar patterns of recovery. Regarding the results of the year 2016, a similar tendency was observed, with untreated plants ( $0 \mathrm{mM} \mathrm{SiK}$ ) exhibiting an increase of about 89 and $68 \%$, on $E$ and $g_{s}$, respectively. Therefore, Si application in chestnut trees limited the increase of $E$ and $g_{\mathrm{s}}$, being the RWC (Fig. 2A) strikingly higher of about $65.6 \%(10$ $\mathrm{mM} \mathrm{SiK}, 2015)$ than that recorded for untreated plants $(21.1 \%, 2015)(0 \mathrm{mM} \mathrm{SiK})$. One explanation for this data might be the fact that the root system of Si-treated plants continued the water absorption, which is very important to allow the continuous water transport all over the plant under drought conditions, promoting more tolerance to the dehydration of the cellular compounds, contrarily to the Si-untreated plants (Ahmed et al. 2013).

A significant reduction in $E(25 \%$; Fig. $4 B)$ and $g_{\mathrm{s}}(34 \%$; Fig. $4 C)$ was observed in the IP when the Si concen-tration increased ( 0 to $10 \mathrm{mM} \mathrm{SiK})$, on the $32^{\text {th }} \mathrm{d}$ in 2015. Consistently, in 2016, at the end of the assay, the Si-untreated plants showed the highest values of $E[1.03$ $\operatorname{mmol}\left(\mathrm{H}_{2} \mathrm{O}\right) \mathrm{m}^{-2} \mathrm{~s}^{-1}$; Fig. $\left.4 F\right]$ and $g_{\mathrm{s}}\left[55.0 \mathrm{~mol}\left(\mathrm{H}_{2} \mathrm{O}\right) \mathrm{m}^{-2} \mathrm{~s}^{-1}\right.$; Fig. $4 G]$, than that in the Si-treated plants (10 mM SiK).

In the current work, the water-use efficiency (WUE) of NIP (Fig. $4 D, H$ ) showed that the Si-treated plants suffered a remarkable reduction of about $60 \%$ (2015) and $80 \%$ (2016) at $12 \mathrm{~d}$, mainly due to the increase of $E$ (Fig. $4 B, F$ ) and $g_{\mathrm{s}}$ (Fig. $4 C, G$ ), which was therefore responsible for losing a large amount of water. In contrast, the Si-fertilized plants exhibited higher values of WUE because they used the water that they absorbed through the roots more efficiently, so that even under drought conditions, they still kept much of the water, which was the main reason for the Si-induced lower values of $E$ and $g_{s}$. In addition, there were no significant changes in WUE between 0 and the $12^{\text {th }} \mathrm{d}$ of water stress.

Comparing the NIP with the IP (Fig. 4D,H), Siapplication caused a significant decrease in water loss and an increase of the WUE in plants, by the increase in $P_{\mathrm{N}}$ and the reduction in $E$. Beside that, Si helped keep the WUE, as the $\mathrm{Si}$ concentration increased ( 0 to $10 \mathrm{mM} \mathrm{SiK})$ from 2.67 to $5.80 \mu \mathrm{mol}\left(\mathrm{CO}_{2}\right) \mathrm{mol}^{-1}\left(\mathrm{H}_{2} \mathrm{O}\right), 118 \%$ more (Fig. $4 D$ ) in 2015 and of about $341 \%$ (Fig. $4 H$ ) in 2016.

The results of the ANOVA test of the gas-exchange measurements for $P_{\mathrm{N}}, E, g_{\mathrm{s}}$, and WUE from the results of 2015 and 2016 assays are shown in Table 2S (supplement). According to that, the treatment was the main influence factor since the variation in $P_{\mathrm{N}}, E$, and WUE is explained by it at about $82.5,38.9$, and $65.1 \%$, respectively (Table $2 \mathrm{~S}$ ). For $g_{\mathrm{s}}$ the main influence factor is the phase (NIP or IP), $37.9 \%$ in 2015. Similar results were observed in 2016, 
the $P_{\mathrm{N}}, E$, and WUE presented 56.2, 54.7, and 51.2\%, respectively, influenced by the Si-treatment applied, while the $g_{\text {s }}$ was significantly influenced by the present/absence of irrigation, by $60.5 \%$.

Leaf photosynthetic pigments: As shown in Table 3, at the end of the NIP, the Chl $(a+b)$ content was significantly higher in the Si-treated plants, varying between $25.6 \mathrm{mg}$ $\mathrm{g}^{-1}(\mathrm{DM})(5 \mathrm{mM} \mathrm{SiK})$ and $32.0 \mathrm{mg} \mathrm{g}^{-1}(\mathrm{DM})(10 \mathrm{mM} \mathrm{SiK})$, while the untreated plants $(0 \mathrm{mM} \mathrm{SiK})$ recorded only $20.4 \mathrm{mg} \mathrm{g}^{-1}(\mathrm{DM})$, representing an increase of about $57 \%$ between 0 and $10 \mathrm{mM} \mathrm{SiK}$ treatment. Similar results were observed in 2016, when the Si-treated plants showed an increase in the $\mathrm{Chl}(a+b)$ content, from $20.0 \mathrm{mg} \mathrm{g}^{-1}(\mathrm{DM})$ (0 mM SiK) to $33.8 \mathrm{mg} \mathrm{g}^{-1}$ (DM) (10 mM SiK), more than $69 \%$ after exposure to water deficit. Data presented in Table 3 suggest that the $\mathrm{Si}$ application in chestnut plants alleviated the negative effects of drought stress on the photosynthetic pigments, allowing for the highest $\mathrm{Chl}$ $a / b$ and $\mathrm{Chl}(a+b)$ contents (Tables 3,4$)$ compared to the untreated plants. These results correlated with higher $P_{\mathrm{N}}$ values recorded in the Si-treated plants (Fig. $4 A$ ) in the NIP.

Concerning carotenoids (Car), the results indicate that Si fertilization promoted the Car production at the end of the NIP, an increase of about $57 \%(10 \mathrm{mM} \mathrm{SiK})$, than that in the untreated plants $(0 \mathrm{mM} \mathrm{SiK})$ in 2015 (Table 3). The results obtained in 2016 showed a similar tendency under water deficit, the Si-treated plants $(10 \mathrm{mM} \mathrm{SiK})$ showed an increase of about $55 \%$ in Car content compared to the untreated plants (0 mM SiK) (Table 4). Consequently, $\mathrm{Chl} / \mathrm{Car}$ was lower in the Si-treated plants than that in the untreated plants in NIP and IP in 2015 (Table 3) and 2016 (Table 4).

Regarding the Chl $a / b$ ratio in the NIP, the Si-treated plants $(10 \mathrm{mM} \mathrm{SiK})$ exhibited a higher ratio of 4.32 than the untreated plants, 3.47 (0 mM SiK) in 2015 (Table 3), leading to a higher increase in 2016, from 1.18 to 2.95 , between 0 and $10 \mathrm{mM} \mathrm{SiK}$ treatments $(150 \%$ increase; Table 4). Analyzing the results obtained in the IP, no significant differences were observed in 2015 and in 2016.

\section{Discussion}

Several reports have shown that silicon application contributes to the increase of drought resistance in plants (Shi et al. 2016, Zanneti et al. 2016). However, the information about the effect of silicon in chestnuts in terms of water stress is very scarce.

These findings suggest that $\mathrm{Si}$ can be accumulated in the vegetal tissues (Table 1) acting as a physical barrier that has an important role in reducing permeability to water vapor, reducing cuticle transpiration, limiting the loss of water, and thus promoting higher $\Psi_{\mathrm{w}}$ in chestnut plants. Previous results verified that $\mathrm{Si}$ is deposited in the xylem vessels and prevents the collapse of the vessels under high transpiration due to drought, resulting in an increase in the water-use efficiency of the plant (Zhu et al. 2005). These results are in agreement with the findings of Gao et al. (2004) and Kaya et al. (2006) in maize plants, where high accumulation of $\mathrm{Si}$ in water stressed leaves may be attributed to its transport in xylem vessels as a silicic acid from the roots to aerial plant tissues, where it is polymerized as a silica. Under drought conditions, Si-treated plants $(10 \mathrm{mM} \mathrm{SiK})$ showed higher $\Psi_{\mathrm{w}}$ (Fig. 1) and RWC (Fig. 2) than the untreated plants (0 mM SiK), indicating that Si can alleviate drought stress, enhancing the water retention in stressed plants, thus allowing the plants to use the available water for their physiological and metabolic needs in a much more effective way (Figs. 1, 2,

Table 3. Effect of SiK fertilization on photosynthetic pigment content of chestnut plants in the non-irrigation phase (NIP) and in the irrigation phase (IP). These results refer to the 2015 assay and data are the mean of six replicates per treatment $(n=6)$. Different lowercase letters mean significant differences between different treatments at the same time according to the Tukey's test $(P \leq 0.05)$. Different capital letters mean significant differences between the same treatment all over the time according to the Tukey's test $(P \leq 0.05)$. ${ }^{* * *} P \leq 0.001,{ }^{* *} P \leq 0.01,{ }^{*} P \leq 0.05$, ns - nonsignificant, according to ANOVA test. Chl $(a+b)$ - total chlorophyll; Car - carotenoids; $\mathrm{Chl} / \mathrm{Car}-$ chlorophyll to carotenoids ratio; Chl $a / b-\mathrm{Chl} a$ to $\mathrm{Chl} b$ ratio.

\begin{tabular}{|c|c|c|c|c|c|}
\hline Time & Treatment [mM SiK] & $\operatorname{Chl}(a+b)\left[\mathrm{mg} \mathrm{g}^{-1}(\mathrm{DM})\right]$ & Car $\left[\mathrm{mg} \mathrm{g}^{-1}(\mathrm{DM})\right]$ & Chl $a / b$ & $\mathrm{Chl} / \mathrm{Car}$ \\
\hline \multirow[t]{4}{*}{ NIP } & 0 & $20.4^{\mathrm{dB}}$ & $3.02^{\mathrm{cB}}$ & $3.47^{\mathrm{aA}}$ & $8.43^{\mathrm{aA}}$ \\
\hline & 5 & $25.6^{\mathrm{cB}}$ & $3.71^{\mathrm{bA}}$ & $2.54^{\mathrm{bB}}$ & $6.90^{\mathrm{bB}}$ \\
\hline & 7.5 & $29.8^{\mathrm{bB}}$ & $4.48^{\mathrm{aA}}$ & $2.33^{\mathrm{bA}}$ & $6.65^{\mathrm{bA}}$ \\
\hline & 10 & $32.0^{\mathrm{aA}}$ & $4.73^{\mathrm{aA}}$ & $4.32^{\mathrm{aA}}$ & $6.76^{\mathrm{bA}}$ \\
\hline \multirow[t]{4}{*}{ IP } & 0 & $23.5^{\mathrm{cA}}$ & $2.91^{\mathrm{cA}}$ & $3.28^{\mathrm{aA}}$ & $8.07^{\mathrm{aB}}$ \\
\hline & 5 & $28.2^{\mathrm{bA}}$ & $3.98^{\mathrm{bA}}$ & $3.05^{\mathrm{bA}}$ & $7.01^{\mathrm{bA}}$ \\
\hline & 7.5 & $31.3^{\mathrm{bA}}$ & $4.59^{\mathrm{aA}}$ & $2.73^{\mathrm{cA}}$ & $6.80^{\mathrm{bA}}$ \\
\hline & 10 & $33.4^{\mathrm{aA}}$ & $4.85^{\mathrm{aA}}$ & $3.56^{\mathrm{aB}}$ & $6.88^{\mathrm{bA}}$ \\
\hline \multicolumn{6}{|c|}{ Variation factor } \\
\hline \multicolumn{2}{|l|}{ Treat. } & $94.7^{* * *}$ & $51.0^{* * *}$ & $53.2^{* * *}$ & $23.8^{*}$ \\
\hline \multicolumn{2}{|c|}{ NIP/IP } & $1.30^{\mathrm{ns}}$ & $25.0^{\mathrm{ns}}$ & $25.8^{* *}$ & $37.8^{* *}$ \\
\hline \multicolumn{2}{|c|}{ Treat. $\times$ NIP/IP } & $0.360^{\mathrm{ns}}$ & $7.59^{\mathrm{ns}}$ & $12.6^{*}$ & $0.600^{\mathrm{ns}}$ \\
\hline \multicolumn{2}{|c|}{ Residual } & 3.64 & 16.4 & 8.30 & 37.9 \\
\hline
\end{tabular}


Table 4. Effect of SiK fertilization on photosynthetic pigment content of chestnut plants in the non-irrigation phase (NIP) and in the irrigation phase (IP). These results refer to the 2016 assay and data are the mean of six replicates per treatment $(n=6)$. Different lowercase letters mean significant differences between different treatments at the same time according to the Tukey's test $(P \leq 0.05)$. Different capital letters mean significant differences between the same treatment all over the time according to the Tukey's test $(P \leq 0.05)$. $\mathrm{Chl}(a+b)$ - total chlorophyll; Car - carotenoids; Chl/Car - chlorophyll to carotenoids ratio; Chl $a / b-\mathrm{Chl} a$ to $\mathrm{Chl} b$ ratio.

\begin{tabular}{|c|c|c|c|c|c|}
\hline Time & Treatment [mM SiK] & $\operatorname{Chl}(a+b)\left[\mathrm{mg} \mathrm{g}^{-1}(\mathrm{DM})\right]$ & $\operatorname{Car}\left[\mathrm{mg} \mathrm{g}^{-1}(\mathrm{DM})\right]$ & Chl $a / b$ & $\mathrm{Chl} / \mathrm{Car}$ \\
\hline \multirow[t]{4}{*}{ NIP } & 0 & $20.0^{\mathrm{aA}}$ & $2.2^{\mathrm{cA}}$ & $1.18^{\mathrm{bA}}$ & $7.27^{\mathrm{aB}}$ \\
\hline & 5 & $27.8^{\mathrm{bB}}$ & $3.5^{\mathrm{bA}}$ & $2.59^{\mathrm{aA}}$ & $7.94^{\mathrm{aA}}$ \\
\hline & 7.5 & $29.1^{\mathrm{aB}}$ & $4.7^{\mathrm{aA}}$ & $2.76^{\mathrm{aA}}$ & $6.19^{\mathrm{bA}}$ \\
\hline & 10 & $33.8^{\mathrm{aB}}$ & $4.9^{\mathrm{aA}}$ & $2.95^{\mathrm{aA}}$ & $6.90^{\mathrm{bA}}$ \\
\hline \multirow[t]{4}{*}{ IP } & 0 & $22.0^{\mathrm{cB}}$ & $2.5^{\mathrm{cB}}$ & $1.85^{\mathrm{bA}}$ & $8.80^{\mathrm{aA}}$ \\
\hline & 5 & $26.1^{\mathrm{bA}}$ & $3.9^{\mathrm{bA}}$ & $2.90^{\mathrm{aA}}$ & $6.69^{\mathrm{bB}}$ \\
\hline & 7.5 & $31.8^{\mathrm{aA}}$ & $5.2^{\mathrm{aB}}$ & $3.21^{\mathrm{aA}}$ & $6.12^{\mathrm{bA}}$ \\
\hline & 10 & $35.4^{\mathrm{aA}}$ & $5.7^{\mathrm{aB}}$ & $3.68^{\mathrm{aA}}$ & $6.21^{\mathrm{bA}}$ \\
\hline \multicolumn{6}{|c|}{ Variation factor } \\
\hline \multicolumn{2}{|c|}{ Treat. } & $66.3^{* * *}$ & $6.1^{\mathrm{ns}}$ & $31.2^{*}$ & $80.7^{* * *}$ \\
\hline \multicolumn{2}{|c|}{ NIP/IP } & $28.70^{*}$ & $63.0^{* *}$ & $14.4^{\mathrm{ns}}$ & $0.004^{\text {ns }}$ \\
\hline \multicolumn{2}{|c|}{ Treat. $\times$ NIP/IP } & $0.001^{*}$ & $1.23^{*}$ & $0.689^{*}$ & $19.30^{* *}$ \\
\hline \multicolumn{2}{|c|}{ Residual } & 5.07 & 29.7 & 53.8 & 0.017 \\
\hline
\end{tabular}

4D,H). Zhang et al. (2013) also verified a similar pattern in young Si-treated chestnuts.

When comparing SiK treatments, the behaviour was quite similar, despite the $5 \mathrm{mM} \mathrm{SiK}$ plants capacity to preserve $\Psi_{\mathrm{w}}$ in the NIP (Fig. 1). These results are consistent with the higher vulnerability to cavitation (Table 2, Fig. 4S) recorded for the untreated plants $(0 \mathrm{mM} \mathrm{SiK})$, indicating that the drought can easily induce xylem cavitation, contrarily to the Si-treated plants. These results reveal the importance of silicon in promoting the maintenance of higher $\Psi_{\mathrm{w}}$ values (Fig. 1), avoiding the cavitation in xylem (Table 2, Fig. 4S) and consequently increasing the tolerance to drought as described by Ahmed et al. (2013) for sorghum plants. This is also coherent with the Ming et al. (2012) and Zanetti et al. (2016) results for rice and cacao plants since they concluded that $\mathrm{Si}$ application can increase or maintain the $\Psi_{\mathrm{w}}$ values. Similar results were obtained by Kaya et al. (2006), Ahmad and Haddad (2011), and Rubinowska et al. (2014) in Si-fertilized corn, wheat, and Solomon's seal, where under water deficit $\mathrm{Si}$ influences osmoregulation and decreases water loss during the transpiration process, which increases the RWC value.

The information concerning the effects of $\mathrm{Si}$ on stomatal density in the literature is very scarce. The present results indicate that SD may have higher plasticity as an adaptation response to water deficit situations. As shown in Figs. 3 and 3S, the Si-treated plants showed a lower SD, reflecting an attempt to use water efficiently under water deficit. Data are corroborated by the study of Gong et al. (2005), which explained that Si has the ability to decrease transpiration via the cuticle or the stomata, due to its involvement in the regulation of the stomatal movement. These findings are also reinforced by the studies of Zargar and Agnihotri (2013), Putra et al. (2015), and Zanetti et al. (2016) in maize, oil palm, and cacao plants; they reported that $\mathrm{Si}$ application reduced the $\mathrm{SD}$, an important factor to reduce $g_{s}$, which improved the water status of plants under drought stress. Many studies have described how a minor SD is associated with the high $P_{\mathrm{N}}$ and WUE in plants under drought stress conditions, as corroborated by us in our study (Fig. 4) (Wang et al. 2013). The maintenance of leaf water status suggested that the chestnut has some defense mechanisms to maintain cell function when the plant is subjected to water stress, as verified by Habibi and Hajiboland (2013) in pistachio plants. Klooster and Palmer-Young (2004) and Rao et al. (2015) explained that a clear adaptation to drought is the presence of a low SD in plants, which enhances drought tolerance by saving the water availability and reducing water loss in plants.

Concerning the xylem studies, data suggest that Si can mitigate the adverse effects of drought by increasing the VD of xylem vessels. The untreated plants $(0 \mathrm{mM} \mathrm{SiK})$ induced the lower VF and VD in the NIP under water stress, leading to a reduction in the uptake and transport of water by plants under water stress (Table 2). These results suggest that Si fertilization in chestnut plants can help the hydraulic balance under water stress.

The Si fertilization promoted the higher VF (Table 2) with lower VD (Table 2) and VA (Table 2) n chestnut plants, contributing to the higher RC (Table 2) and xylem diameter (Table 2) values and, consequently, lower $E$ (Fig. 4B,F). These results can be associated with the higher WUE (Fig. 4D,H), $\Psi_{\mathrm{w}}$ (Fig. 2), and RWC (Fig. 2) in the Si-treated plants in the NIP. The untreated plants recorded a lower diameter of xylem (Table 2), a decrease in the water uptake and transpiration, which was aggravated by water deficit, leading to cavitation and the embolism of xylem vessels (Fig. 1). The lower vulnerability to cavitation recorded in plants treated with 7.5 and $10 \mathrm{mM}$ SiK concentrations is consistent with the lower values of $E$ (Fig. $4 B, F$ ) and $g_{\mathrm{s}}$ (Fig. $4 C, G$ ), accompanied by the higher $P_{\mathrm{N}}$ (Fig. $\left.4 A, E\right)$ and $\Psi_{\mathrm{w}}$ (Fig. 1) in the NIP and the 
IP, which can be explained by the Si application promoting higher VF and VD (Table 2), possibly leading to an improvement in the resistance of chestnut plants to water stress.

VD influenced the low or higher RC, with wider vessels transporting a larger amount of water more efficiently than narrow vessels, in addition to having a higher vulnerability to cavitation resistance (Gutiérrez et al. 2009). In this context, the highest concentrations of Si used in the current study ( $7.5 \mathrm{mM}$ and $10 \mathrm{mM} \mathrm{SiK})$ led to a higher number of vessels with a lower diameter and consequently to higher $\mathrm{RC}$, allowing the vessels to transport larger water amounts from roots to leaves than that in the untreated plants (0 mM SiK) (Table 2). These findings are also in accordance with the studies of Chen et al. (2016) and Shi et al. (2016) in sorghum and tomato plants; they reported that $\mathrm{Si}$ improved the hydraulic conductance in xylem vessels and consequently the water uptake associated with the water stress tolerance.

Drought stress promoted a higher reduction in $P_{\mathrm{N}}$ in the untreated plants $(0 \mathrm{mM} \mathrm{SiK})$ than that in the Si-treated plants (10 mM SiK), which demonstrated a slight decrease in this gas-exchange parameter, in proportion to the amount of silicon supplied to chestnuts plants (Fig. 4A,E). Data are corroborated by the studies of Zhang et al. (2013) in chestnut plants. These results can be explained by the fact that the presence of $\mathrm{Si}$ inside the plants promoted a better arrangement of leaves, making them more upright to avoid excessive self-shading. This allowed the senescence to be slowed and improved the structural rigidity of tissues, thus preventing the degradation of Chl (Tables 2, 3). On the other hand, the lower values of $P_{\mathrm{N}}$ in the untreated plants can be explained by the higher water loss that caused the closure of the stomata (Fig. 4C,G), which consequently decreased the $P_{\mathrm{N}}$ (Fig. $4 A, E$ ). This is because the stomata aperture is a direct response to the leaf water status as described by Comstock (2002). When comparing the NIP and the IP, the results indicate that the Si supplementation can limit the impairment of the $P_{\mathrm{N}}$ upon the drought stress condition and allow the plants a fast recuperation when the water deficit ends. On the other hand, the untreated plants with lower values of $P_{\mathrm{N}}$ (Fig. $4 A, E$ ) and higher values of $E$ (Fig. $4 B, F$ ) and $g_{\mathrm{s}}$ (Fig. $4 C, G$ ) did not recover completely from this abiotic stress, never reaching the $P_{\mathrm{N}}, E$, and $g_{\mathrm{s}}$ values of the Si-treated plants $(10 \mathrm{mM} \mathrm{SiK})$. Moreover, the untreated plants were the ones that suffered more damage from the insufficient soil water to maintain the vital physiological processes of plants, presenting a higher reduction of Chl $(a+b)$ content (Tables 2, 3) and a lower survival rate for plants under water deficit (Fig. 1), only $30 \%$ at the end of the study. These trends also confirmed earlier reports that $\mathrm{Si}$ fertilization improves the tolerance of plants to drought stress (Agarie et al. 1998, Hattori et al. 2005) in rice and sorghum plants. Similar results were obtained by Lux et al. (2002) and Gao et al. (2006) in sorghum and maize plants, respectively.

When the comparison between NIP and IP is made, relatively to $E$ and $g_{\text {s }}$ (Fig. 4), the results suggest that $\mathrm{Si}$ fertilization in chestnut plants limits the effect of drought, indicating that $\mathrm{Si}$ can promote root length, enhancing the area of water absorption of the Si-treated plants.
Moreover, data suggest that Si can reduce water loss by evapotranspiration through the silicification of the leaf surface and the decrease in the diameter of stomatal pores, which is corroborated by a greater leaf water potential $\left(\Psi_{w}\right.$; Fig. 1) and RWC (Fig. 2) in the Si-treated plants (10 mM $\mathrm{SiK})$. The present findings confirm the studies of Habibi and Hajiboland (2013) in pistachio plants. Furthermore, Si-treated plants showed a tendency for rapid recoveries between the transition of the NIP to the IP (between the $12^{\text {th }}$ and $13^{\text {th }} \mathrm{d}$ ), with a higher decrease in $E$ (Fig. $4 B, F$ ) and $\mathrm{g}_{\mathrm{s}}$ (Fig. $\left.4 C, G\right)$ than that in the untreated plants $(0 \mathrm{mM}$ $\mathrm{SiK})$, accompanied by the increase in the water-holding capacity and enhancing the water content of leaves in the Si-treated plants (Fig. 4D, $H$ ), followed by a stabilization of these parameters until the end of the study. These findings are similar to those of Hattori et al. (2005) and Gong and Chen (2012), who reported that Si application improved the reduction of hydraulic resistance following a high root activity, by promoting better root development, which improved water movement from the rhizosphere to the roots, increasing the water status of sorghum and wheat in fields with drought conditions.

Hattori et al. (2005) added that a higher silicon deposition in the cell walls of the epidermis prevents excessive water loss through transpiration and in the xylem vessels prevents compression of the vessels in sorghum plants. The same authors added that $\mathrm{Si}$ application can improve the development of the endodermis cells for better root resistance to dry soils and faster root growth to explore a larger volume of soil than untreated plants.

Chestnut plants supplied with Si showed the significant increase in photosynthetic pigments under drought conditions. The present findings are corroborated by Zhang et al. (2013), who described how Si application led to higher photosynthetic pigment [Chl $(a+b)$ and $\mathrm{Chl} a / b]$ amount under drought conditions. This happens due to the presence of Si inside the plants, promoting the decrease in these metabolites caused by water deficit. In this regard, Silva et al. (2012) and Asgharipour and Mosapour (2016) found that $\mathrm{Si}$ fertilization increases the Chl content, reducing the oxidative stress while protecting the cell and the chloroplast membranes, which contributes to the osmotic adjustment in tomato and fennel plants.

Conclusions: Si fertilization with 7.5 and $10 \mathrm{mM} \mathrm{SiK}$ promoted a higher tolerance of chestnut plants to water stress under drought, reducing the negative effects of this abiotic stress. The parameters available in 2015 and 2016 indicated a similar tendency in both years in the Si-treated chestnuts, reinforcing the results presented in this work. In conclusion, the use of $\mathrm{Si}$ in chestnuts represents an important and beneficial alternative for the future by helping the farmers protect their trees from drought stress. Consequently, it could improve the yield of this important crop in Europe.

\section{References}

Agarie S., Hanaoka N., Ueno O. et al.: Effects of silicon on tolerance to water deficit and heat stress in rice plants (Oryza sativa L.), monitored by electrolyte leakage. - Plant Prod. 
Sci. 1: 96-103, 1998.

Aguiar C.: Três notas sobre o castanheiro (Castanea sativa, Fagaceae). Das plantas e das pessoas, 2009. [Three notes on the chestnut (Castanea sativa, Fagaceae). Of plants and people.] http://plantas-e-pessoas.blogspot.pt/2009/10/ tres-notas-sobre-o-castanheiro-castanea.html. Accessed: 27 December 2016. [In Portuguese]

Ahmad S.T., Haddad R.: Study of silicon effects on antioxidant enzyme activities and osmotic adjustment of wheat under drought stress. - Czech J. Genet. Plant Breed. 47: 17-27, 2011.

Ahmed M., Kamran A., Asif M. et al.: Silicon priming: a potential source to impart abiotic stress tolerance in wheat: A review. Aust. J. Crop Sci. 7: 484-491, 2013.

Asgharipour M.R., Mosapour H.: A foliar application silicon enhances drought tolerance in fennel. - J. Anim. Plant Sci. 26: 1056-1062, 2016.

Ashraf M., Afzal M., Ahmad R. et al:: Silicon management for mitigating abiotic stress effects in plants. - Plant Stress 4: 104-114, 2010.

Chen D., Cao B., Wang S. et al.: Silicon moderated the K deficiency by improving the plant-water status in sorghum. Sci. Rep.-UK 6: 22882, 2016.

Comstock J.P.: Hydraulic and chemical signaling in the control of stomatal conductance and transpiration. - J. Exp. Bot. 53: 195-200, 2002.

Conedera M., Tinner W., Krebs P. et al:: Castanea sativa in Europe: distribution, habitat, usage and threats. - In: San-Miguel-Ayanz J., de Rigo D., Caudullo G. et al. (ed.): European Atlas of Forest Tree Species. Pp. 78-79. Publication Office of the European Union, Luxembourg 2016.

Farooq M., Hussain M., Wahid A., Siddique K.H.M.: Drought stress in plants: an overview. - In: Aroca R. (ed.): Plant Responses to Drought Stress. Pp. 1-33. Springer, Berlin 2012.

Gao X., Zou C., Wang W., Zhang F.: Silicon improves water use efficiency in maize plants. - J. Plant Nutr. 27: 1457-1470, 2004.

Gao X., Zou C., Wang L., Zhang F.: Silicon decreases transpiration rate and conductance from stomata of maize plants. - J. Plant Nutr. 29: 1637-1647, 2006.

Gong H., Zhu X., Chen K. et al.: Silicon alleviates oxidative damage of wheat plants in pots under drought. - Plant Sci. 169: 313-321, 2005.

Gong H.J., Chen K.M.: The regulatory role of silicon on water relations, photosynthetic gas exchange, and carboxylation activities of wheat leaves in field drought conditions. - Acta Physiol. Plant. 34: 1589-1594, 2012.

Gutiérrez M., Miguel-Chávez R.S., Terrazas T.: Xylem conductivity and anatomical traits in diverse lianas and small tree species from a tropical forest of southwest Mexico. - Int. J. Bot. 5: 279-286, 2009.

Habibi G., Hajiboland R.: Alleviation of drought stress by silicon supplementation in pistachio (Pistacia vera L.) plants. - Folia Hortic. 25: 21-29, 2013.

Hattori T., Inanaga S., Araki H. et al.: Application of silicon enhanced drought tolerance in Sorghum bicolor. - Physiol. Plantarum 123: 459-466, 2005.

Kaya C., Tuna L., Higgs D.: Effect of silicon on plant growth and mineral nutrition of maize grown under water-stress conditions. - J. Plant Nutr. 29: 1469-1480, 2006.

Klooster B., Palmer-Young E.: Water stress marginally increases stomatal density in E. canadensis, but not in A. gerardii. Tillers 5: 35-40, 2004.

Korndörfer G.H., Pereira H.S., Nolla A.: Análise de silício: solo, planta e fertilizante. [Silicon analysis: soil, plant and fertilizer.] $2^{\text {nd }}$ Edition. Pp. 34. Instituto de Ciências Agrárias, Universidade Federal de Uberlândia, 2004. [In Portuguese]
Krebs P., Conedera M., Pradella M. et al.: Quarternary refugia of the sweet chestnut (Castanea sativa Mill.): an extended palynological approach. - Veg. Hist. Archaeobot. 13: 145160, 2004.

Lichtenthaler H.K.: Chlorophylls and carotenoids: Pigments of photosynthetic biomembranes. - Method. Enzymol. 148: 350382, 1987.

Lionello P., Abrantes F., Gacic M. et al.: The climate of the Mediterranean region: research progress and climate change impacts. - Reg. Environ. Change 14: 1679-1684, 2014.

Lux A., Luxová M., Hattori T. et al.: Silicification in sorghum (Sorghum bicolor) cultivars with different drought tolerance.Physiol. Plantarum 115: 87-92, 2002.

Mattioni C., Cherubini M., Micheli E. et al.: Role of domestication in shaping Castanea sativa genetic variation in Europe. - Tree Genet. Genom. 4: 563-574, 2008.

Mauad M., Crusciol C.A.C., Nascente A.S. et al.: Effects of silicon and drought stress on biochemical characteristics of leaves of upland rice cultivars. - Rev. Ciênc. Agron. 47: 532-539, 2016.

Mellano M.G., Beccaro G.L., Donno D. et al.: Castanea spp. biodiversity conservation: colletion and characterization of the genetic diversity of an endangered species. - Genet. Resour. Crop Ev. 59: 1727-1741, 2012.

Ming D.F., Pei Z.F., Naeem M.S. et al.: Silicon alleviates PEGinduced water-deficit stresses in upland rice seedlings by enhancing osmotic adjustment. - J. Agron. Crop Sci. 198: 14-26, 2012.

Mota M., Pinto T., Vilela A. et al.: Irrigation positively affects the chestnut's quality: The chemical composition, fruit size and sensory attributes. - Sci. Hortic.-Amsterdam 238: 177186, 2018.

Othomani A., Ayed S., Chamekh Z. et al.: Silicon alleviates adverse effect of drought stress induced by polyethylene glycol (PEG 8000) on seed germination and seedling growth of durum wheat varieties. - J. Electron. Commun. Eng. 11: 33-36, 2016.

Pimentel D.: Climate changes and food supply. - Forum Appl. Res. Public Policy 8: 54-60, 1993.

Putra E.T.S., Issukindarsyah T., Purwanto B.H.: Physiological response of oil palm seedlings to the drought stress using boron and silicon applications. - J. Agron. 14: 49-61, 2015.

Rao Y., Yang Y., Xu J. et al.: EARLY SENESCENCE1 encodes a SCAR-LIKE PROTEIN2 that affects water loss in rice. Plant Physiol. 169: 1225-1239, 2015.

Rosenzweig C., Parry M.L., Fischer G., Frohberg K.: Climate Change and World Food Supply. Research Report No. 3. University of Oxford, Oxford 1993.

Rubinowska K., Pogroszewska E., Laskowska H. et al:: The subsequent effect of silicon on physiological and biochemical parameters of Polygonatum multiflorum (L.) All. 'Variegatum' cut shoots. - Acta Sci. Pol.-Hortoru. 13: 167-178, 2014.

Salisbury F.B., Ross C.: Plant Physiology. Pp. 45. Prentice Hall of India, Pvt. Ltd., New Delhi 1969.

Šesták Z., Čatský J., Jarvis P.G.: Plant Photosynthetic Production: Manual of Methods. Pp. 818. Dr. W. Junk NV, The Hague 1971.

Shi Y., Zhang Y., Han W. et al.: Silicon enhances water stress tolerance by improving root hydraulic conductance in Solanum lycopersicum L. - Front. Plant Sci. 7: 196, 2016.

Silva O.N., Lobato A.K., Ávila F.W. et al.: Silicon-induced increase in chlorophyll is modulated by the leaf water potential in two water deficient tomato cultivars. - Plant Soil Environ. 58: 481-486, 2012.

Twumasi P., Ieperen W.V., Woltering E.J. et al.: Effects of water stress during growth on xylem anatomy, xylem functioning 
and vase life in three Zinnia elegans cultivars. - Acta Hortic. 669: 303-312, 2005

Wang S.G., Li Z.Q., Jia S.S. et al.: [Relationships of wheat leaf stomatal traits with wheat yield and drought resistance.] Chin. J. Appl. Ecol. 24: 1609-1614, 2013. [In Chinese]

Xu Z., Zhou G.: Responses of leaf stomatal density to water status and its relationship with photosynthesis in a grass. J. Exp. Bot. 59: 3317-3325, 2008.

Zanetti L.V., Milanez C.R.D., Gama V.N. et al.: Leaf application of silicon in young cacao plants subjected to water deficit. Pesqui. Agropecu. Bras. 51: 215-223, 2016.

Zargar S.M., Agnihotri A.: Impact of silicon on various agro- morphological and physiological parameters in maize and revealing its role in enhancing water stress tolerance. - Emir. J. Food Agr. 25: 138-141, 2013.

Zhang C., Moutinho-Pereira J.M., Correia C. et al.: Foliar application of Sili-K ${ }^{\circledR}$ increases chestnut (Castanea spp.) growth and photosynthesis, simultaneously increasing susceptibility to water deficit. - Plant Soil 365: 211-225, 2013.

Zhu X., Gong H., Chen G. et al.: Different solute levels in two spring wheat cultivars induced by progressive field water stress at different developmental stages. - J. Arid. Environ. 62: 1-14, 2005.

(C) The authors. This is an open access article distributed under the terms of the Creative Commons BY-NC-ND Licence. 